\section{METALS SOLUTIONS}

\section{PremoMet Alloy, an alternative to cobalt containing alloys}

Carpenter Technology Corporation has announced the availability of Carpenter PremoMet alloy, which is presented as a lower-cost alternative to many cobalt-containing steel alloys. With its strength, toughness and fatigue resistance characteristics, PremoMet alloy is to be considered for high-demand power train components in heavy-duty diesel engines and other commercial transportation and locomotive applications.

PremoMet alloy is available in bar, hollow bar, wire, strip, plate and billet forms and can be plated. Thanks to its advanced strength and fracture toughness properties, this new quenched and tempered alloy steel may enable designers to lighten the weight of parts for highload applications by as much as $25 \%$. The weight reduction estimates are based on the attainable ultimate tensile strength of 2,040 MPa (296 ksi) combined with the fracture toughness which is much higher than the lower-strength alternatives. Lighter-weight components also result in a reduction of stress on other parts, and lower energy consumption throughout a product's lifecycle.

\begin{tabular}{l|c|c|c|c}
\hline \multicolumn{1}{c|}{ Property } & $\begin{array}{c}\text { Heat-treated } \\
\text { steel,e.g. } \\
42 \mathrm{CrM04/4140} \\
25 \mathrm{MoCr4/8620}\end{array}$ & $\begin{array}{c}\text { Bearing steel } \\
52100 \\
\text { Fe-1C-1.45Cr }\end{array}$ & $\begin{array}{c}\text { High strength } \\
\text { heat-treated } \\
\text { steel,e.g. } \\
\text { 34CrNiM06/4340 }\end{array}$ & $\begin{array}{c}\text { PremoMetTM } \\
\text { Alloy }\end{array}$ \\
\hline $\begin{array}{l}\text { Ultimate tensile Strength } \\
\text { (Mpa) }\end{array}$ & $900-1160$ & 1380 & $1200-1850$ & 2040 \\
\hline Yield strength (Mpa) & $700-800$ & 1275 & $1000-1550$ & 1680 \\
\hline Fatigue strength (Mpa) & $450-600$ & $800-900$ & $550-875$ & 1000 \\
\hline Elongation at break (\%) & 14 & 3 & 10 & 12 \\
\hline Reduction of area (\%) & 53 & 30 & 40 & 46 \\
\hline $\begin{array}{l}\text { Fracture toughness } \\
\mathrm{k}_{\mathrm{k}}(\mathrm{Mpa} \mathrm{V} m \text { ) }\end{array}$ & 62 & 21 & 60 & 88 \\
\hline
\end{tabular}

Material data are typical values only. Source: Carpenter Corp

\section{Optimized superalloy from ThyssenKrupp VDM in marine diesel engine valves}

Ever higher demands are being placed on the materials used in the construction of modern diesel engines for freight and passenger ships: tighter emissions standards and rising oil prices call for greater energy efficiency, while at the same time increasing amounts of horsepower are being extracted from ever smaller engines. This progress has resulted in a significant increase in operating temperatures in the com- bustion chamber. These high temperatures are pushing the materials currently used in this area to their limits. As a response, ThyssenKrupp VDM has optimized its nickel superalloy Alloy $80 \mathrm{~A}$ for use in the valves of large two-stroke marine diesel engines. High-temperature corrosion resistance has been significantly improved by an increased chromium content, while the strength of the material has been maintained by the use of further alloying elements. Modern large marine diesel engines in the 4,000 to $80,000 \mathrm{~kW}$ power range can weigh up to 2,300 tons, ThyssenKrupp points out; the valves used in them are up to two meters in size and weigh 300 kilograms. They are exposed to high mechanical stresses and at risk from hot gas corrosion: the combustion chamber is subject to high temperatures, which in combination with the heavy oil used in large diesel engines attack the surface of the valve stems, causing heavy corrosion. The material used for the valves therefore has to be particularly corrosion-resistant and long-lasting. The aim in developing materials for valve stems is to further improve these properties: ThyssenKrupp VDM developed its new superalloy in cooperation with the Finnish engine maker Wärtsilä and the valve manufacturer Märkisches Werk Halver.

Märkisches Werk Halver offered the infrastructure necessary to validate and implement the new material in the valve stem application. "The performance of the valve stem is closely linked to the quality of the material," says project worker Rainer Weigelt from Märkisches Werk Halver. In one of the first tests a valve was made from the new material and fitted in the engine of a container ship. "The results of long-term field testing were very promising," explains Dr. Dietmar Schlager, who headed the project for Wärtsilä. "Now we're testing six further valves and we expect these field tests to deliver more information on production readiness."

The new material also has great potential in other areas. It can be used wherever high demands are placed on high-temperature corrosion resistance in connection with aggressive oil. "We see outstanding prospects for the material in the auto area as well," says Dr. Jutta Klöwer, project manager at ThyssenKrupp VDM, "particularly given the trend towards more powerful engines with higher combustion chamber temperatures."

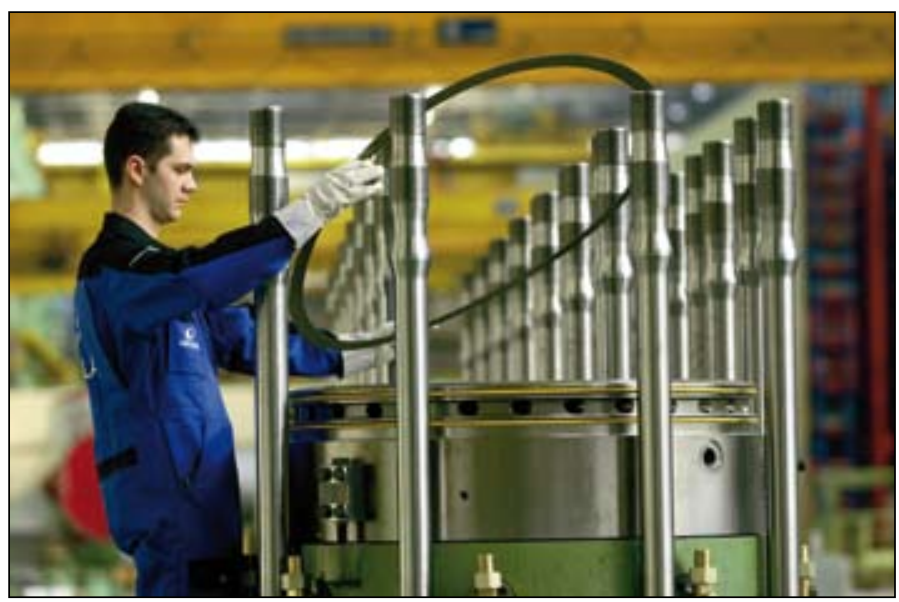

Power solutions specialist Wärtsilä successfully tested the valves. Source: Wärtsilä 


\section{"metaklett", a stainless steel hook and loop fastener}

Since it was first registered for patent by the Swiss inventor Georges de Mestral in 1951, the Velcro hook and loop fastener has become a commonplace item, used to fasten everything from clothing and shoes to bandages to wiring sleeves in cars. Now it has been taken a stage further: a hook and loop closure made of temperature-resistant stainless steel has been awarded this year's Steel Innovation Prize by the German Steel Industry Association. The material for this new invention is supplied by the manufacturer of stainless flat products ThyssenKrupp Nirosta Präzisionsband $\mathrm{GmbH}$, in Schalksmühle. Flexible, easy to use and long lasting, Velcro strip has established itself as an invaluable fastener in a wide range of applications. These have been limited by the material from which it is made - usually plastic, which makes it unsuitable for use in hot environments or where it might come into contact with chemicals. That's why hook and loop closures have never previously been used in the engine compartment of vehicles. This is due to change with the new Velcro fastener made of stainless steel, developed by employees of the companies Reinz Dichtungs $\mathrm{GmbH}$, Neu-Ulm, an automotive supplier in the field of metal sealing products (cylinder-head gaskets, thermal acoustic shield components and valve bonnets) and Hölzel Stanz- und Feinwerktechnik GmbH \& Co. KG, Wildberg specialized in tooling project consulting, development and realization. Under a project managed by Reinz Dichtungs $\mathrm{GmbH}$, the cooperation partners came up with various fastener geometries and investigated their manufacturing and joining behavior at the forming and foundry faculty of Munich Technical University. "metaklett" is the first hook and loop fastener made of metal. It offers all the advantages of a Velcro system combined with the strength of stainless steel.

"The challenge was to find a material which is strong and at the same time very flexible to achieve the required hook consistency," says
Kurt Höhe, head of advance development and technology at ReinzDichtungs-GmbH. Like the plastic variant, "metaklett" consists of two strips, one with loops and one with hooks. When they are pressed together, the hooks and loops engage. The closure is opened by pulling the strips/components apart (shearing/peeling) with the result that the hooks are released from the pile. Kurt Höhe: "After they are disengaged from the loops, the hooks must return to their original shape to ensure that the closure can be used many hundreds of times with no loss of performance". Hölzel Stanzund Feinwerktechnik now has the job of manufacturing the metal hook and loop closures. The joint invention has already been registered for patent.

The search for the right material led the developers to ThyssenKrupp Nirosta Präzisionsband. "The spring properties of the material Nirosta 4310 meet all requirements in terms of strength and flexibility. After strain hardening, Nirosta 4310 acquires ideal properties for applications subject to alternating loads. In addition, the material is suitable for stamping, embossing, flanging and profiling, and is therefore the optimum choice for the production process at Hölzel Stanz- und Feinwerktechnik", says Heiko Wilken from the ThyssenKrupp Nirosta Präzisionsband sales team.

Two "metaklett" variants are available: "metaklett Flamingo" and "metaklett Entenkopf" (duck's head), with the names referring to the shape of the hooks. Both variants comprise a $0.2 \mathrm{~mm}$ thick hook strip and a $0.2 \mathrm{~mm}$ thick punched or stamped pile strip of stainless spring steel. They are resistant to chemicals and can withstand tensile loads of up to 35 metric tons per square meter even at $600{ }^{\circ} \mathrm{C}$. Despite this strength, the closure can be opened and closed quickly without the use of tools, like a Velcro fastener. A further variant combines a stainless steel hook strip with a plastic pile strip. "metaklett" is meant for applications requiring a secure fastening which can be opened easily when required, e.g. for attaching ventilation and cable ducts in buildings or heat shields in the auto industry.

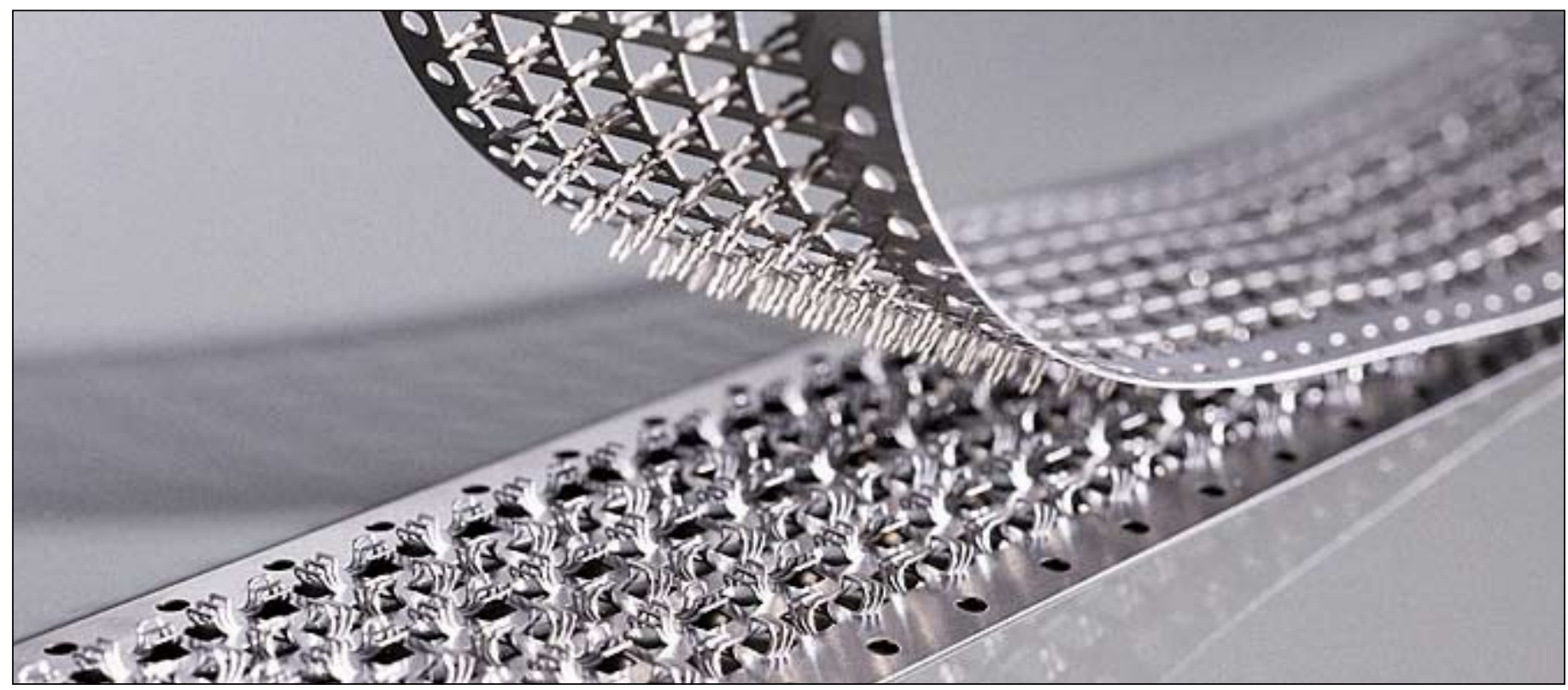

The advantages of a Velcro system combined with the strength and heat resistance of stainless steel. Source: Hölzel Stanz 


\section{INDUSTRY CONTRACTS}

\section{Corus supplies wind towers construction parts}

Corus has unveiled a steel product for the renewable energy market following development work at its UK research labs.

Corus Special Profiles in Skinningrove, North East England, has secured five European orders so far for its steel product, which is used in the construction of wind towers. The orders were secured following development work by Corus engineers in Scunthorpe and Skinningrove (Teesside), as well as at the company's research labs in Rotherham.

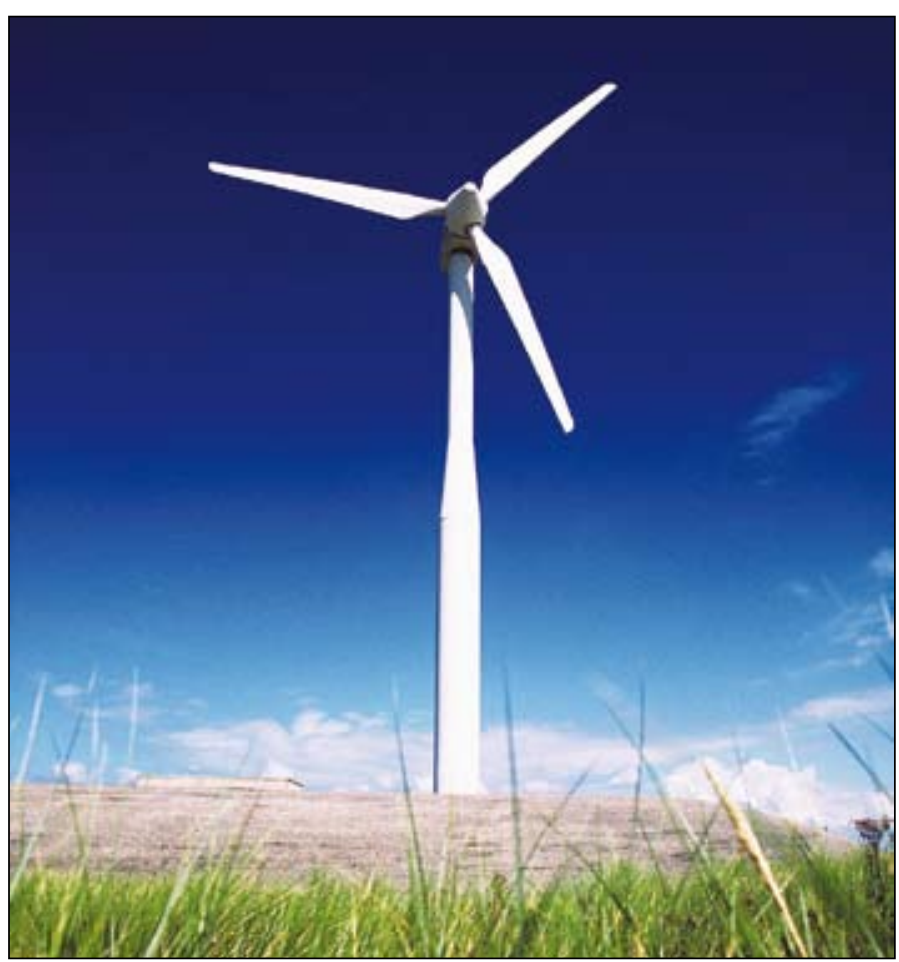

Wind turbines, a rapidly growing market Source: World Steel Association

The steel is manufactured in Scunthorpe and transported to Skinningrove where steelworkers reheat it to $1,250^{\circ} \mathrm{C}$ before rolling it into the desired shape, according to customers' requirements. The end product - a bar of steel that typically measures 15 metres in length and weighs 4 tonnes - undergoes inspection and testing, including ultrasonic scans, to ensure it is free from defects. The steel is then shipped to manufacturers of flanges, which are used to join sections of tubular steel in the construction of towers for wind turbines.

According to Corus, the demand for wind turbines is growing rapidly around the world and the market for this specialist steel product is thought to be worth almost $£ 100 \mathrm{~m}$ a year. Chris Elliot, Corus director of product line management, said: "This is part of our strategy to capture the increasing value of fast-growing industrial sectors, in this case renewable energy."

\section{ThyssenKrupp Aerospace: 10-year contract with EADS subsidiary}

ThyssenKrupp is further expanding its internationally aerospace business operations. Through its subsidiary ThyssenKrupp Aerospace Germany $\mathrm{GmbH}$, it has concluded with Premium Aerotec $\mathrm{GmbH}$, a member of the EADS Group and supplier of Airbus, a ten-year contract for supply chain services.

As part of the contract, ThyssenKrupp Aerospace, as part of ThyssenKrupp's Business Area Materials Service, is investing some $€ 20$ million at Premium Aerotec's Varel, Friesland, northern Germany, production location. The commitment comprises the construction of an ultramodern $12,500 \mathrm{~m}^{2}$ logistics and processing center as well as the operation of a supplier park to be set up, the Aeropark. The complex will provide jobs for over 100 persons.

The key businesses of Premium Aerotec are structures and manufacturing systems for aircraft production including engineering and development. A key decision criterion for the new partnership in the opinion of the customer was ThyssenKrupp Aerospace's longstanding expertise as integrated materials services provider. The contract covers the premachining and final machining of finished parts as well as single-source logistics.

In taking this step, Premium Aerotec is focusing the hitherto decentralized upstream manufacturing stages at the former Airbus site. "Among the objectives targeted by our customer is for other suppliers of material-related services to move to the new Aeropark in order to secure in the long term the competitiveness and the growth prospects of the plant," explains Claude Weber, Member of the of the business area Material Services Management Team.

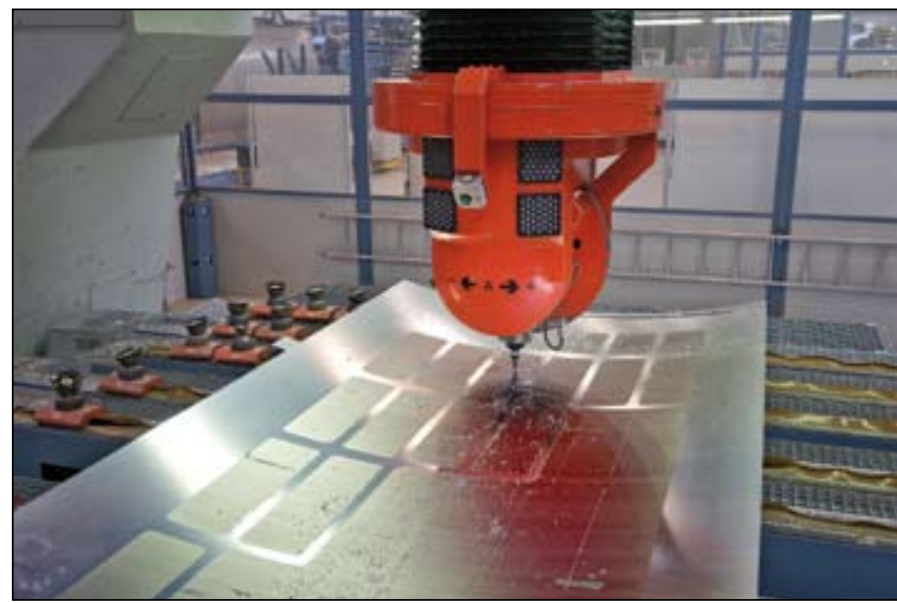

Outline milling at Premium Aerotec. Source:Premium Aerotec 
“ThyssenKrupp Aerospace will operate the Aeropark for ten years at first. In this way we are significantly strengthening our European aerospace business and creating the facilities for additional materials services capacities."

At the new logistics and processing center, ThyssenKrupp Aerospace will annually saw and mill some 14,000 tons of aluminum sheets. Other services embrace in-plant logistics, the identification of parts and components, finishing, incoming materials services, and shipments. "We will make sure that the materials are shipped out just in time to Premium Aerotec and its subcontractors", Weber adds.

Stuart Wilkins, President of ThyssenKrupp Aerospace, comments: "We are convinced that this integration of foremost manufacturers and their suppliers at a single location will help optimize cost structures at both ends. This agreement is the first of its kind in Europe and for our sector a pioneering move."

\section{Corus announces EUR35m}

\section{investment in French steel mill after securing rail contract}

Corus will invest EUR35 million at its rail production facility in Hayange, France, after securing a major new contract with SNCF. The investment follows the confirmation that Corus has secured a contract worth about EUR350 million to supply rails for up to six years to French railway operator SNCF for the renewal and maintenance of the RFF (Réseau Ferré de France) tracks. The contract is for an initial four years with the option to extend it by a further two years.

Corus will invest EUR35 million in new technology at its rail production facility in Hayange, in the Lorraine region of north-east France, to allow it to produce longer rails. The investment in a range of new manufacturing equipment will improve the plant's efficiency and enable workers to produce 108-metre long rails.

With main steelmaking operations primarily in the UK and the Netherlands, Corus - a subsidiary of Tata Steel - supplies steel and related services to the construction, automotive, packaging, mechanical engineering and other markets worldwide. Gérard Glas, Director General of Corus Rail (France), said: "Being able to produce 108-metre long rails opens up new opportunities for us and puts us in a better position to supply the growing demand for high-speed rail lines. By 2011 we will be among just a handful of producers with this world-class capability. This significant contract with SNCF also gives us the confidence to invest in our Hayange plant."

Engineering studies have already been completed at the Hayange plant. At the peak of the enhancement work, up to 400 contractors are expected to be working on the upgrade - from design and mechanical engineers to electricians and demolition experts. Colin McGibbon, Hayange plant manager, said: "This is the largest and most significant investment in the Hayange site for more than a decade. The investment will make us more competitive and help secure the future of the plant

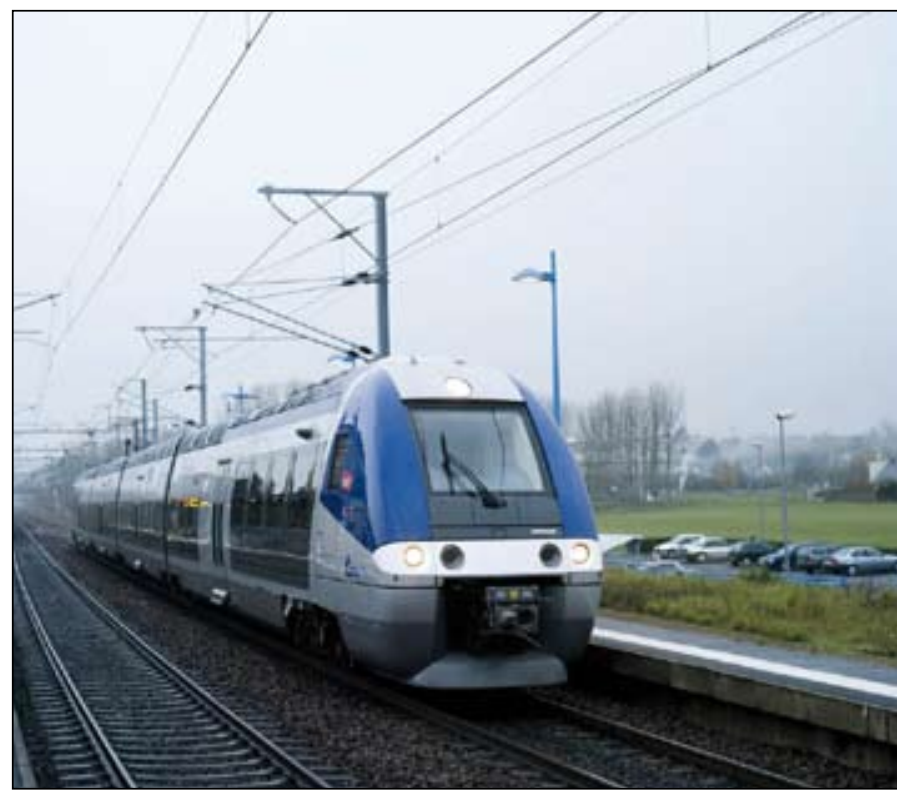

The Hayange facility will produce 108-metre long rails for high-speed rail lines.

Source: RFF

- and the workforce - for years to come." The Hayange mill, which employs 440 people, currently supplies rails of varying lengths to railway operators around the world, but predominantly in Europe. The mill can currently produce rails of up to 80 -metres in length. The investment will improve yield and quality at the plant, as well as boosting production capacity from 300,000 to 340,000 tons per year.

\section{Nord Stream: second phase, 1 billion euro pipe contracts}

The Nord Stream Project, an offshore natural gas pipeline project due to link Russia and the European Union via the Baltic Sea, will result in two offshore pipelines, each being approximately $1,220 \mathrm{~km}$ in length, laid on the seabed of the Baltic Sea. The second pipeline of the Nord Stream project will also be routed from Vyborg, north-west of St. Petersburg, to Lubmin, Germany. Nord Stream AG is an international joint venture company established for the planning, construction and subsequent operation of the Nord Stream Pipeline. Russian OAO Gazprom holds a 51 percent stake of the joint venture. German companies, BASF/Wintershall Holding AG and E.ON Ruhrgas AG, hold 20 percent each, and a Dutch gas infrastructure company, N.V. Nederlandse Gasunie, has a 9 percent stake.

EUROPIPE - a joint subsidiary owned $50 \%$ by Dillinger Hütte and $50 \%$ by Salzgitter AG - will supply large-caliber welded linepipe for line 2. As Dillinger Hütte chairman Dr. Paul Belche affirms, "This is an important order for Dillinger Hütte and will assure a good portion of our basic capacity utilization level for a number of months". Dillinger Hütte will supply $50 \%$ of EUROPIPE's linepipe plate needs for this project.

According to Dillinger Hütte, the contract has a total volume of approximately one billion euro, of which $65 \%$ has been awarded to EUROPIPE, $25 \%$ to Russian pipe producer OMK and 10\% to Sumitomo. 
Sumitomo Metal Industries and Sumitomo Corporation, confirm they have won a contract from Nord Stream AG to supply large diameter welded (UOE) line pipes, for the second phase of the Nord Stream project - a contract worth 91 million euro. The awarded work includes coating arrangement and delivery to destinations in Germany and Finland. The Japanese companies mention, in the previous tender for the Line 1 (which took place in 2007 for approximately 1 million tons of pipes), they did not receive order.

Sumitomo will supply high strength UOE line pipes (ID $1,153 \mathrm{~mm} x$ WT $30.9 \mathrm{~mm}, 110 \mathrm{~km}$ ), with coating on the inner and outer walls (Grade SAWL 485 I FD, equivalent to X70). Bare pipes are to be produced in Sumitomo Metals' Kashima Steel Works, while a process of coating is to be arranged by Sumitomo Corp. On-site delivery of Sumitomo coated pipes will start September 2010.

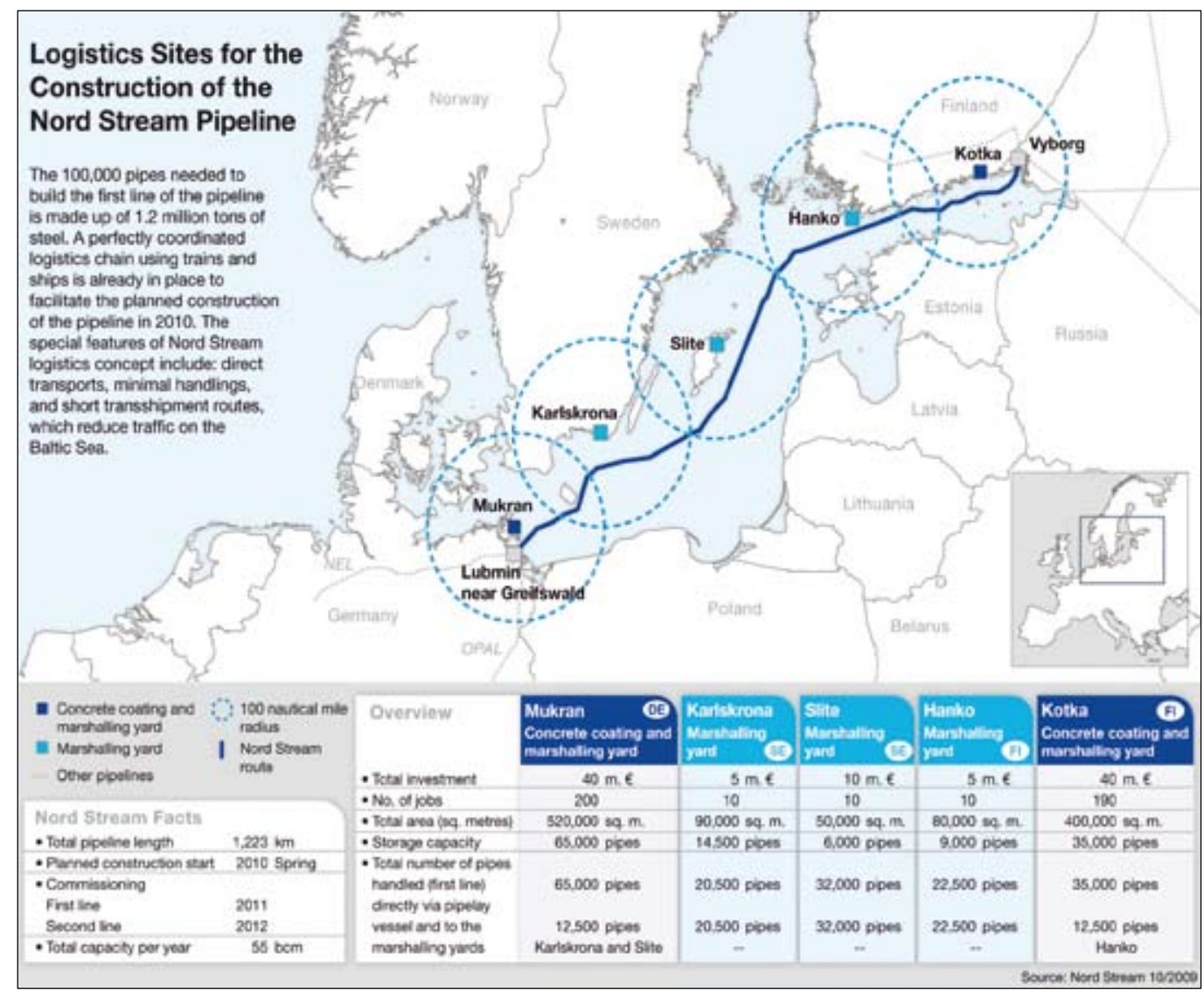

Logistics sites for the construction of the Nord Stream Pipeline. Source: Nord Stream AG

\section{Dillinger Hütte: 3 construction projects achieved in 2009}

Following the opening of the Porsche Museum in January 2009, the Golden Ears Bridge opened in Vancouver and construction of the Alpha Ventus offshore wind farm power plant is underway.

One special construction project using steel from Dillingen - the Golden Ears Bridge in Vancouver, Canada - opened in June 2009. For years, traffic jams have hindered the flow of people and goods on both sides of the Fraser River in the eastern part of this city on the Pacific coast. To solve this problem, Canada's TransLink transportation authority ordered the construction of the six-lane Golden Ears cable-stayed bridge, with a total length of 960 meters.

The bridge, which is decorated with statues of eagles, is named for the nests of the eagles ("Golden Aeries") that were characteristic of the region in former times. Dillinger Hütte supplied a total of 6,500 tons of steel for the project. After about 10 years of planning and construction, the Golden Ears Bridge is now being opened to traffic earlier than originally planned, and in time for the 2010 Olympic Winter Games in Vancouver.

The Porsche Museum in Stuttgart-Zuffenhausen opened its doors to the public back in January 2009. Since then, aside from the rou-

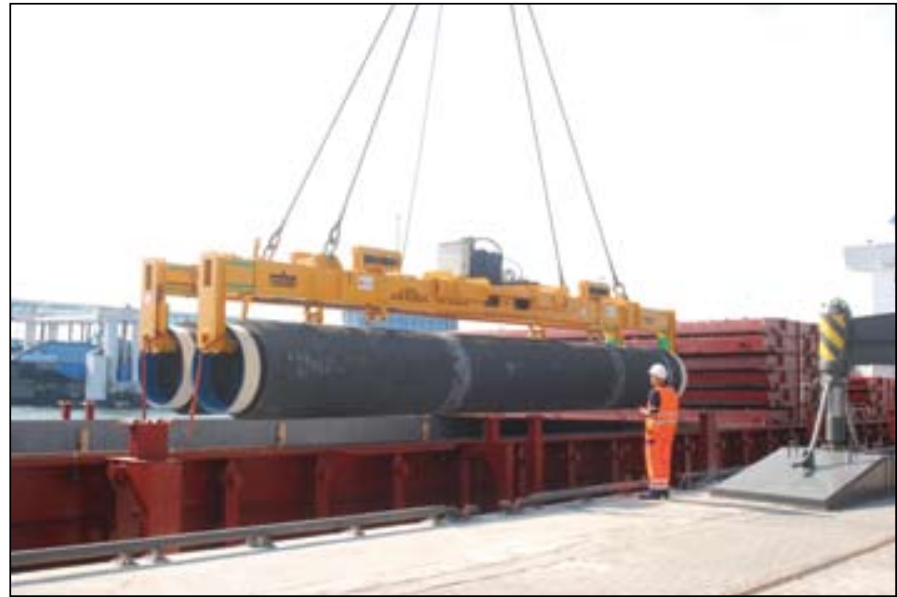

Large diameter pipes for the offshore pipelines. Source: Nord Stream AG

ghly 80 exhibitions, countless visitors have also admired the architecture of the museum, which employed steel from Dillingen in its construction. The highlight of the building designed by the architects Delugan Meissl in Vienna: the main structure of the museum appears to "float," resting on only three roughly 16 -foot high reinforced concrete stilts. Meanwhile, this main structure - known as the "airplane" - weighs about 32,000 tons - an architectural tour de force and the result 
of complex statistical calculations. Dillinger Hütte supplied about 950 tons of heavy plate for this futuristic building.

With the construction of the first German offshore wind farm, known as Alpha Ventus, a third project that employs heavy plate steel supplied by Dillinger Hütte is currently underway. Alpha Ventus is being built about 45 kilometers north of the North Sea island of Borkum.

It is considered a test field that will provide insight for the future commercial use of offshore wind power plants to produce clean energy. Construction of the wind farm will include generators with a peak output of 5 megawatts. With the help of special ships, the wind turbines will be mounted on 700-ton steel tripods made from Dillinger steel, stretching up to 148 meters in height. Dillinger Hütte is supplying a total of 12,800 tons of steel for the Alpha Ventus offshore wind farm.

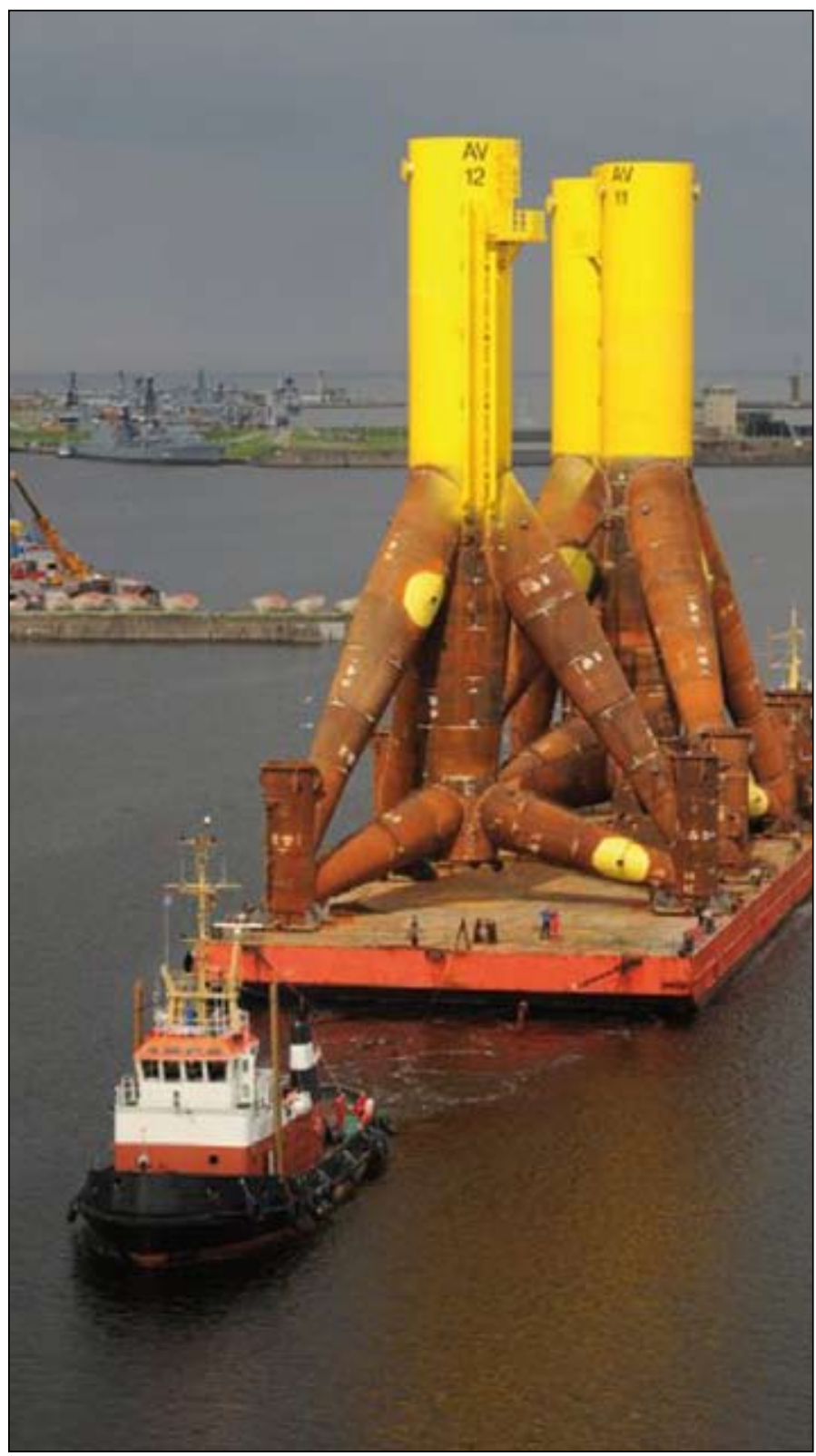

Tripods for the Alpha Ventus Project.

\section{JFE Steel / Marubeni-Itochu Steel: 172,000 tons line pipe order}

JFE Steel Corporation and Marubeni-Itochu Steel Inc. have been awarded a 172,000 tons line pipe orders for Gorgon Natural Gas Project operated by Chevron Australia Pty Ltd: 154 KMT of DNV450 Grade line pipe for the Gorgon and Jansz Export Flowlines, along with 18 KMT of DNV450 Grade line pipe for the Gorgon Domestic Gas Line.

The Gorgon Project is operated by the Australian subsidiary of Chevron in joint venture with the Australian subsidiaries of ExxonMobil and Shell, Osaka Gas, Tokyo Gas and Chubu Electric. The project is developing the Greater Gorgon gas fields, located between $130 \mathrm{~km}$ and $200 \mathrm{~km}$ off the north-west coast of Western Australia. The Greater Gorgon gas fields are estimated to contain resources of about 40 trillion cubic feet of gas, Australia's largestknown gas resource.

As the large diameter line pipes supplied for this project will be used for long distance sub-sea pipeline, they must meet low temperature toughness requirements and have heavy wall thickness (maximum wall thickness: $38.0 \mathrm{~mm}$ ) sufficient to withstand operations under high pressure, along with anti-corrosive properties.

\section{PLANTS AND EQUIPMENTS}

\section{Inteco: project management contract with Qatar Steel}

Steel mill Qatar Steel Company has signed a project management contract with Inteco, Austria, for the upgrading of the existing steel melt shop.

Inteco has already completed basic engineering and constructability studies for Qatar Steel upgrading assignment. The project core equipment will be ordered in second quarter of 2010 and commissioning is planned in the fourth quarter of 2011.

\section{Redaelli launches wire rope production facility in Italy}

Redaelli, tensostructures engineering company and speciality wire ropes manufacturer based in Italy, announces the opening of a new manufacturing facility in Trieste.

The new facility will produce Flexpack compacted nonrotating steel wire ropes, designed for high load, high resistance to axial and transverse pressure applications. The facility will have the 


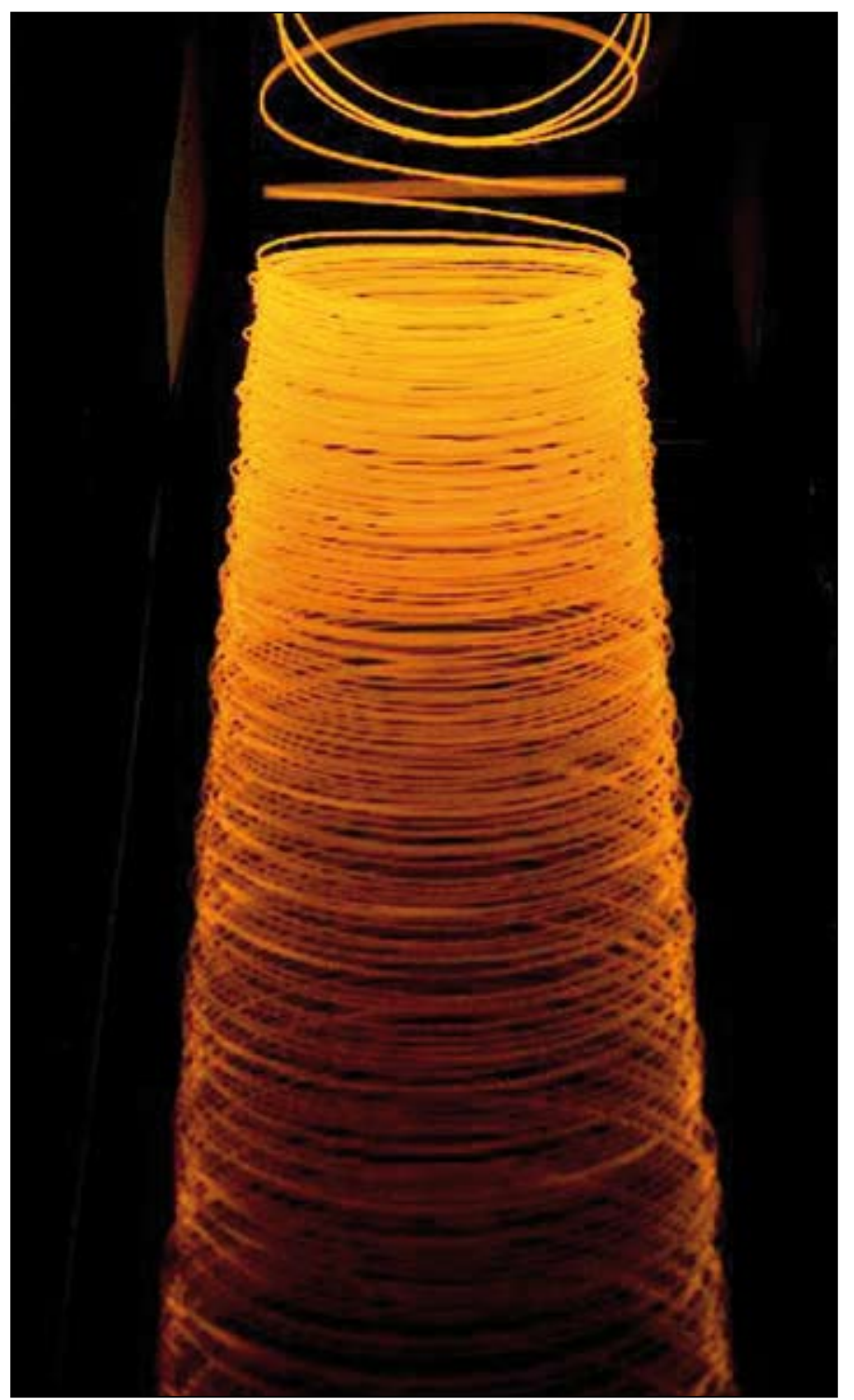

Inteco has already completed basic engineering and constructability studies.

capacity to produce cables that weigh over 550 tons with diameter $175 \mathrm{~mm}$ : according to Redaelli, the current rope weight record will be exceeded by more than 200 tons.

These ropes target sectors such as offshore oil and gas exploration and production. Redaelli's new wire ropes have a higher tensile strength, meant for allowing the platform to remain in position on the extraction site as long as possible and in extreme conditions, such as hurricane or glacial storm.

The new production line will employ 25 people. The investment of more than Euro 12 million in the facility has been made possible through the financial and operational support of Severstal-metiz, Redaelli's parent company, as part of its strategy to strengthen its position in the supply of steel ropes. Notably, the logistics infrastructure in Trieste is capable of handling cargo for international exports.

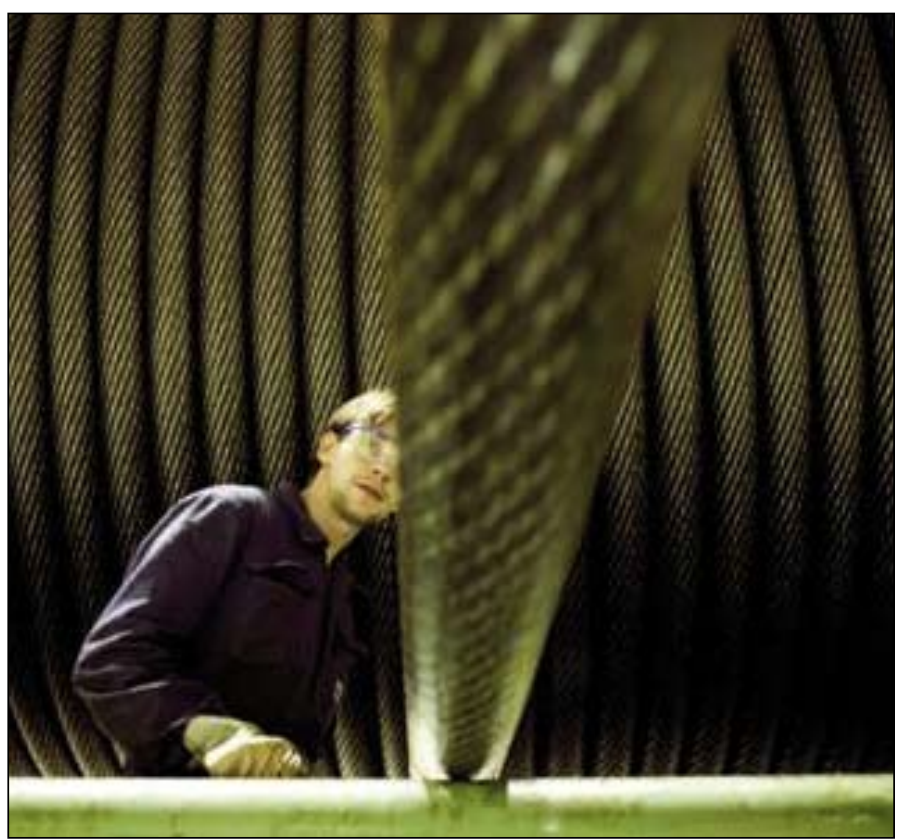

Cables over 550 tons, with diameter $175 \mathrm{~mm}$.

Source: Severstal

\section{Blast furnace construction in progress at NLMK}

Installation of the basic structures at Novolipetsk Steel's new blast furnace \#7 of a 3.4 million tons annual capacity has been completed. The furnace's shell, including its support system, off-gas system, charging device and stove housing, has been installed.

According to NLMK, Blast Furnace No.7 is the first project of its kind in contemporary Russia. New blast furnaces have not been constructed in Russia for over 20 years, since the Soviet Union.

In accordance with the construction schedule, installation of bin trestle for ore and coke material intake and feeding, and installation of the refractory lining, has begun. In 2010 NLMK plans to install basic process equipment. By mid-2011 the automatic process control system should be implemented, and hot testing will begin.

The new blast furnace facility and related units will be located in a 78 hectare area in the southern part of Lipetsk production site. The construction is expected to use 75,000 tons of steel structures, 25,000 tons of refractories and 40,000 tons of process equipment. The facility's infrastructure will also include about $50 \mathrm{~km}$ of new railways and motor roads.

The construction of BF-7 started in 2008. This project is being implemented by NLMK in conjunction with Paul Wurth (Luxemburg) and UZTM (Yekaterinburg) within the framework of Stage II of NLMK's Technical Upgrade Program. The new furnace will increase NLMK's steel-making capacity at its main production site in Lipetsk to 12.4 million tons per year or by $40 \%$ in 2012 . 


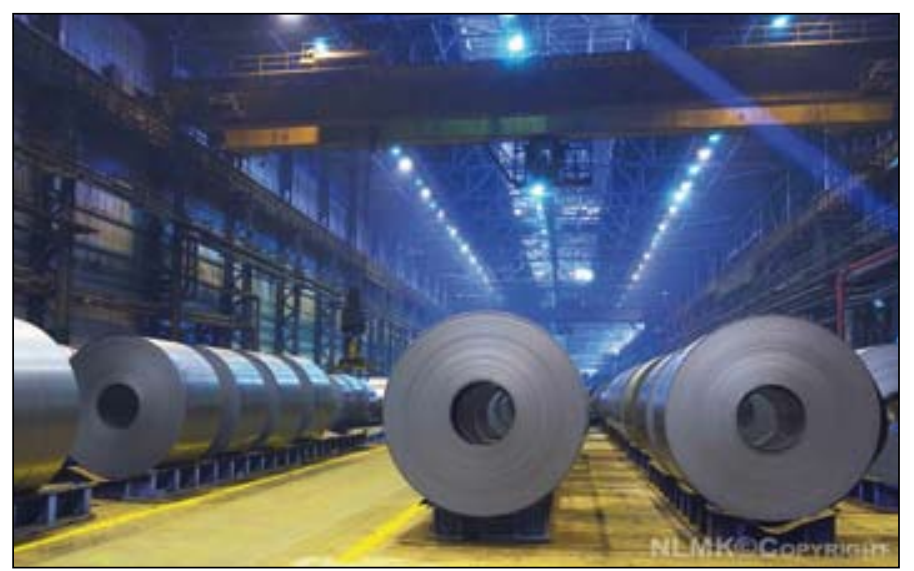

Cold rolled steel produced in main production site in Lipetsk.

\section{Inauguration of Tenova pickling line in ArcelorMittal Poland}

At the end of last year, Tenova, specialized in designing and supplying, products and services for the metal and mining industries, attended the inauguration of the upgraded ArcelorMittal continuous pickling line in Krakow, Poland. Tenova Strip Processing won the upgrading contract in 2008 as a member of a consortium with Miebach and ABB, for the improvement of strip characteristics, mainly through a new tension leveler, a side trimmer, new welding machine and automation of the line.

The revamping of the pickling line has received the industrial commissioning certificate at the end of October 2009. The aim of the revamping is to improve the capacity of the line and the quality parameters of cold rolled steel in mechanical properties, thickness tolerance and high flatness.

The line will produce $1.200 .000 \mathrm{t} / \mathrm{y}$ of steel strip, up to $4,5 \mathrm{~mm}$ thick.

For the same plant Tenova Key Technologies, Tenova Company based in Austria, has been awarded a contract for an acid regeneration plant that connected to the pickling tanks allows to reach a "zero-waste" condition.

\section{PSI: follow-up contract from ThyssenKrupp electrical steel in France}

PSI has been awarded by the producer of grain-oriented electrical steel ThyssenKrupp Electrical Steel, with implementing the production management system PSImetals for the rolling mill and thermal treatment in the electric strip cold rolling mill in Isbergues, France. The goals of ThyssenKrupp Electrical Steel are harmonised processes and reduced expenditures in the IT administration by means of a standardised shop-floor system in all the plants. This order was preceded by the use of PSI systems at the Gelsenkirchen site and the implemen- tation of PSImetals in slitting and packaging in Isbergues. In the future PSImetals will be controlling the production at both European plants and securing the quality across all the processing steps.

PSI AG develops and integrates complete solutions, on the basis of its own software products, for the management of energy networks (electricity, gas, oil, heat, water), cross-company production management (metals, automotive, mechanical and plant engineering, logistics) and infrastructure management for telecommunications, transport and safety.

The solution at ThyssenKrupp is based on the PSImetals components for production execution (PES) and advanced line sequencing (ALS). The specific plant programs will be generated and implemented for all the system types in the rolling mill and the tempering. The cross-plant tracking of the production orders, including the production data acquisition and implementation of the quality standards, is handled the level of the specific plant segment by means of a task-optimised menu. ThyssenKrupp Electrical Steel expects benefits especially in retroactive quality analyses. Every modification and defect, including precise information about where the position of the defect was in which stage of treatment, is shown in a graphical material genealogy for every piece of electrical steel. This quality information forms the basis for the future improvements in the production process.

"The old system was successfully replaced and the ramp-up occurred without incidents. The first strips were cut and packed just a few hours after the conversion of the system. The process was tracked completely by means of PSImetals. We are looking forward to phase 2 , i.e. the introduction of the rolling mill and the tempering with great confidence," reports Guy Ligi, Head of Order Center \& Finishing Operation at ThyssenKrupp Electrical Steel in Isbergues.

The connection to SAP and to the various sub-systems is handled by PSlintegration. The commencement of operations for the rolling mill and thermal treatment is planned for the first half of 2010 .

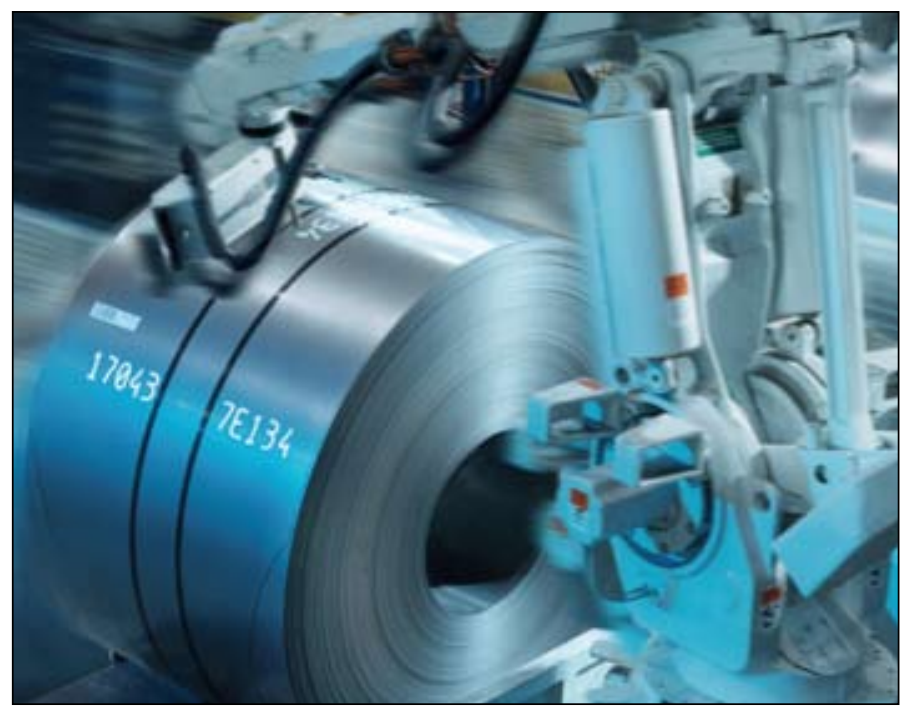

A ThyssenKrupp cold rolling mill. Source: ThyssenKrupp 


\section{ENVIRONMENTAL OUTLOOK}

\section{Corus pilot plant to reduce emissions}

Corus is to test a new iron-making technology in a pilot plant project at its IJmuiden steelworks in the Netherlands. Called "Hisarna", the technology claims to reduce emissions of carbon dioxide in the blast furnace steelmaking route by more than $50 \%$.

The $€ 20$ million project is one of the initiatives that has sprung up under the auspices of ULCOS (Ultra-Low CO2 Steelmaking), a consortium of European steelmakers that has drawn up a programme to reduce the steel industry's carbon footprint.

The Dutch Cabinet of Ministers approved on November 27 a $€ 5$ million contribution to the project. The rest of the investment will come from European Commission research funds and from the ULCOS consortium partners.

The 60,000 tpa Hisarna pilot plant will harness this process; which consists in producting liquid iron from virgin raw materials in just a single step, eliminating two of the three production steps required in blast furnace iron making. According to Corus, Hisarna opens the prospect of a 20\% improvement in steel industry energy efficiency. Commissioning of the pilot plant is foreseen at the end of 2010, after which an intensive test programme will be carried out.

Two technologies have been combined to develop Hisarna. The melting of fine ores in a cyclone has been developed by Corus in IJmuiden. This cyclone will be directly linked to the final process step where the hot metal is formed, this second step is the Hlsmelt process.

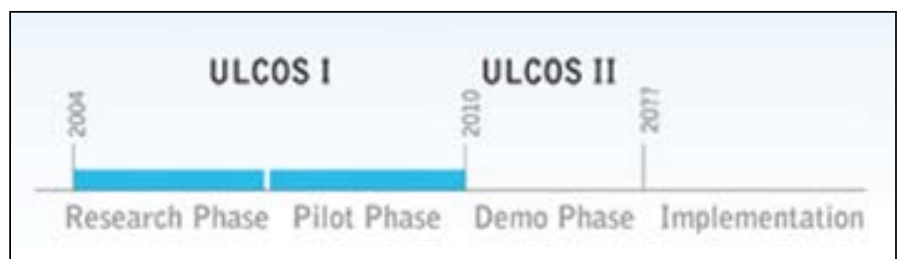

The ULCOS Programme. Source: ULCOS

\section{= China's climate change commitment allows it to increase its $\mathrm{CO} 2$ emissions by 75 to $90 \%$ by 2020}

Eurofer, the European Confederation of Iron and Steel Industries, stresses the need for equal treatment of industrial sec- tors worldwide: "While we recognize the commitment of China to reduce its $\mathrm{CO} 2$ emissions per unit of national income by 40 to $45 \%$ in 2020 compared to 2005 levels we must point out that this would still lead to an increase of its CO2 emissions by 75 to $90 \%$ in 2020, or 5.5 to 6.8 billion tonnes of $\mathrm{CO} 2$, which is more than the total of the EU's $\mathrm{CO}_{2}$ emissions today", says Gordon Moffat, general director of Eurofer. "If any significant step forward to reduce global GHG emissions is to be achieved, and for reasons of fair competition, China and other emerging economies must commit to the same reductions for their industrial installations as the developed countries. Producers of globally traded industrial goods such as steel need a level playing field if carbon leakage is to be avoided and if we wish to see a real reduction in emissions worldwide."

The calculation is made on the basis of an expected growth of China's gross national income of $8 \%$ in average per year in the period from 2005 to 2020. Eurofer refers to a US Congress report, according to which China's GHG emissions in 2005 had been at 5.77 tonnes $\mathrm{CO} 2$ per capita, total $\mathrm{CO} 2$ emissions at 7.53 billion tonnes. China would therefore take about 23.8 billion tCO2 in 2020 as the basis for calculating its objective. As a result, in 2020 this would be at 13.1 to 14.3 billion tCO2, which is an increase in emissions of 5.57 to 6.77 billion tCO2 or $74 \%$ to $90 \%$ compared to 2005 and more than the total of the EU's $\mathrm{CO} 2$ emissions today.

\section{PEOPLE AND ORGANISATION}

\section{ArcelorMittal appoints Peter Kukielski to its Group Management Board and Phil Du Toit to its Management}

ArcelorMittal announces the appointment of Peter Kukielski to its Group Management Board (GMB), with responsibility for the Group's global mining operations, effective $1^{\text {st }}$ January 2010.

Peter Kukielski joined ArcelorMittal in December 2008 as Senior Executive Vice President and Head of Mining, with responsibility for driving further development of ArcelorMittal's mining business. Prior to joining ArcelorMittal, Mr. Kukielski held senior positions at a number of mining companies, notably at Teck Resources, Noranda/Falconbridge (now Xstrata) and Rio Algom (now BHP Billiton).

ArcelorMittal also announces appointment of Philippus F. (Phil) Du Toit to its Management Committee with effect from 1st January 2010. Mr. Du Toit has been Executive Vice President (EVP) of ArcelorMittal and Head of Mining Projects and Exploration since November 2008 and he reports to Peter Kukielski. He has extensive mining experience and prior to moving to ArcelorMittal, he held a senior position at leading mining company Vale. 
Lakshmi N. Mittal, Chairman and CEO of ArcelorMittal, commented: "Peter has shown the strong leadership and expertise we would expect from a member of ArcelorMittal's Group Management Board. He successfully managed our mining business during one of the most challenging periods for the steel industry in recent history. Through his work we have been able to strengthen the foundations for ArcelorMittal to become a truly integrated global steel production and mining business. I am pleased to welcome him to the GMB and I look forward to his continued contribution to the Company's success. I also welcome Phil to our Management Committee; his inputs towards the ongoing development of our mining activities will be important."

\section{Karl-Ulrich Köhler to join Corus as new $\mathrm{COO}$}

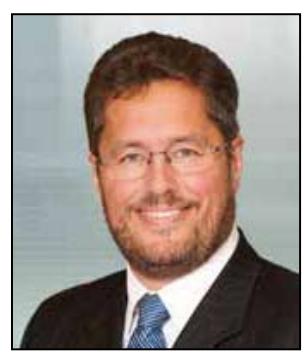

Corus announces the appointment of Dr Karl-Ulrich Köhler as its new Chief Operating Officer with effect from 1 February 2010.

Dr Köhler succeeds Rauke Henstra, who held the position until his retirement last year. He will report to Kirby Adams, Managing Director and CEO of Tata Steel Europe.

Dr Köhler, 53, will be based at IJmuiden in the Netherlands. He has worked during his 30-year steel industry career at the companies that today comprise ThyssenKrupp Steel, where he was most recently Chairman of the Executive Board and a Member of the Board of the parent company, ThyssenKrupp AG. Until October he was President of Eurofer, the European steelmaking federation, in which role he succeeded former Corus CEO Philippe Varin.

Born in Baden-Württemberg, Germany, Dr Köhler studied metallurgy at Clausthal University of Technology, where he gained his doctorate in 1988. In 2005 he was awarded an honorary professorship in flat steel product technology by Freiberg University. Married with four children, Dr Köhler is a former member of the executive committee of the World Steel Association and Vice Chairman of VDEh, the German Iron and Steel Institute.

\section{ThyssenKrupp MetalServ established}

Effective October 15, 2009, the ThyssenKrupp Group has, within the Materials Services business area, reorganized and merged under ThyssenKrupp MetalServ GmbH its central domestic materials trading business activities. The new company employs a workforce of around 800 throughout Germany. It provides logistics and services for production materials such as stainless steels, non-ferrous metals, pipes and tubes. The Management Board consists of Dr. Volker Paetz (CEO), Achim Boner, and Marcus Wöhl.

Included under Düsseldorf-based ThyssenKrupp MetalServ are: the central stainless steel and non-ferrous metal warehouses, the stainless and aluminum service centers, the central pipe/tube warehouses, Stahlkontor Hahn, and the fittings center DAZ (Das Armaturenzentrum). Together these activities generate a sales volume of about one billion Euros. In cooperation with numerous affiliates, the company serves customers on all European markets and specifically materials processors in industry, the craft, and construction trades.

ThyssenKrupp MetalServ's lineup covers over 100,000 items available ex-warehouse. Customers can obtain standard dimensions off the shelf and, if the order is big enough, as a drop shipment. Rounding off the range are extensive size-cutting and other customer-focused services to the formula "made-to-measure materials". ThyssenKrupp MetalServ's central warehouses combined with the additional extensive processing capabilities allow the operating outlets to supply a range of products of vast breadth and depth. According to ThyssenKrupp, the Dortmund location is among Europe's biggest central warehouses for stainless steels and non-ferrous metals and allows cost-efficient inventory management for optimized local service.

"Our infrastructure is rigorously focused on the needs of our customers with their short-notice and varying requirements," summarizes CEO Dr. Volker Paetz. "Each customer obtains their order not only just in time but also to the exact size and shape needed, a one-off prefabricated part or series-produced mass items."

The formula for such high-speed availability combined with overall inventories that are as low as possible is a sophisticated logistics strategy that interlinks the service centers and the central warehouses with the locations of the affiliates and customers.

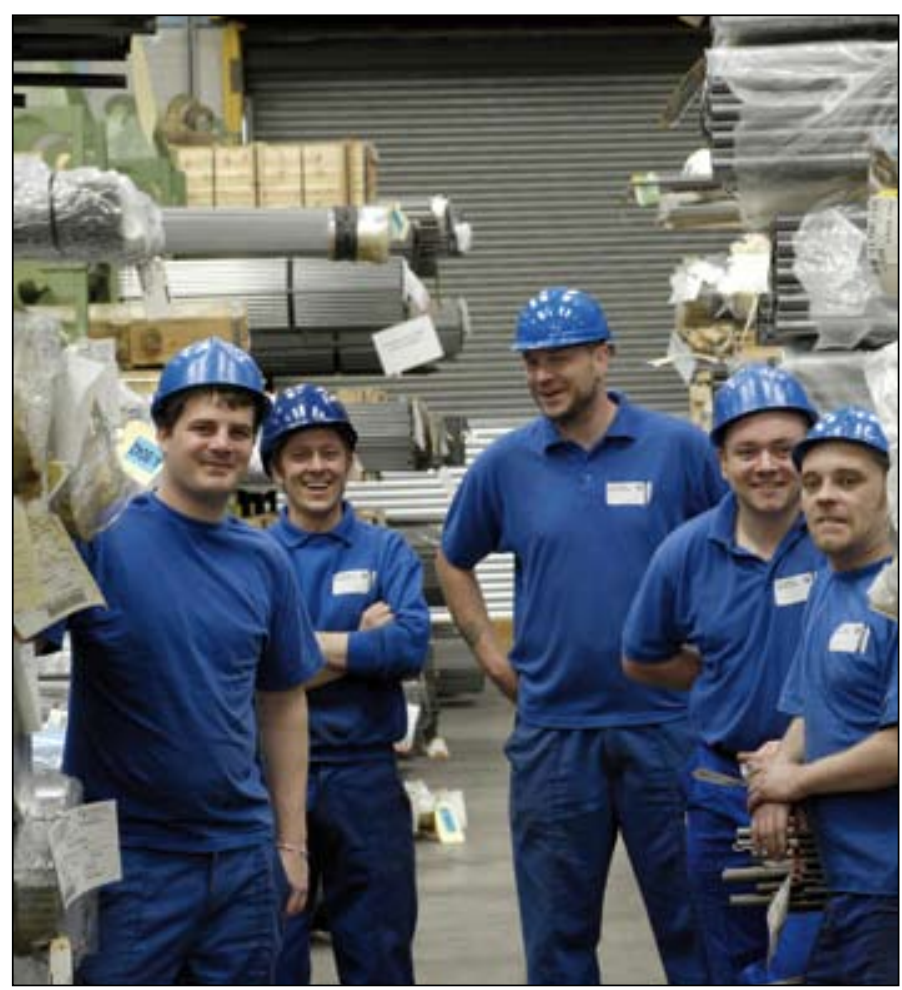

The Materials business area Services combines the warehousing and services business. Source: ThyssenKrupp 


\section{ECONOMY WATCH}

\section{World crude steel output} decreases by $-8.0 \%$ in 2009, growing figures in China and India

According to the World Steel Association, which represents approximately 180 steel producers, world crude steel production reached 1,220 million metric tons for the year of 2009. This is a decrease of $-8.0 \%$ compared to 2008. Steel production declined in nearly all the major steel producing countries and regions including the EU, North America, South America and the CIS in 2009. However, Asia, in particular China and India, and the Middle East showed positive growth in 2009.

In December 2009, world crude steel output for the 66 countries reporting the World Steel Association was $106.4 \mathrm{mmt}$, an increase of $30.2 \%$ compared to December 2008. Most major-steel producing countries showed two-digit growth in December 2009. The world crude steel capacity utilisation ratio of the 66 countries in December 2009 was $71.5 \%$, a decrease from $74.7 \%$ in November 2009. Compared to 2008, the utilisation ratio in December 2009 increased by 13.4 percentage points.

China's crude steel production in 2009 reached $567.8 \mathrm{mmt}$, an increase of $13.5 \%$ on 2008 . This is a record annual crude steel production figure for a single country. China's share of world steel production continued to grow in 2009 producing $47 \%$ of world total crude steel, an increase of 9 percentage points compared to 2008.

Asia produced $795.4 \mathrm{mmt}$ of crude steel in 2009, an increase of $3.5 \%$ compared to 2008 . Its share of world steel production increased to $65 \%$ in 2009 from $58 \%$ in 2008 . Japan produced $87.5 \mathrm{mmt}$ in 2008 , a decrease of $-26.3 \%$ on 2008 . India's crude steel production was $56.6 \mathrm{mmt}$ in $2009,2.8 \%$ growth on 2008 . South Korea showed a decrease of $-9.4 \%$, producing $48.6 \mathrm{mmt}$ in 2009 .

The EU-27 where all major steel producing countries including Germany, Italy and France showed substantial decline recorded a decrease of $-29.7 \%$ compared to 2008 , producing $139.1 \mathrm{mmt}$ of crude steel in 2009.

In 2009, crude steel production in North America was $82.3 \mathrm{mmt}$, a decrease of $-33.9 \%$ on 2008 . The US produced $58.1 \mathrm{mmt}$ of crude steel, $36.4 \%$ lower than 2008.

The CIS showed a decrease of $-14.7 \%$ in 2009 . Russia produced $59.9 \mathrm{mmt}$ of crude steel, a $-12.5 \%$ reduction on 2008 while Ukraine recorded a decrease of $-20.2 \%$ with year-end figures of $29.8 \mathrm{mmt}$.

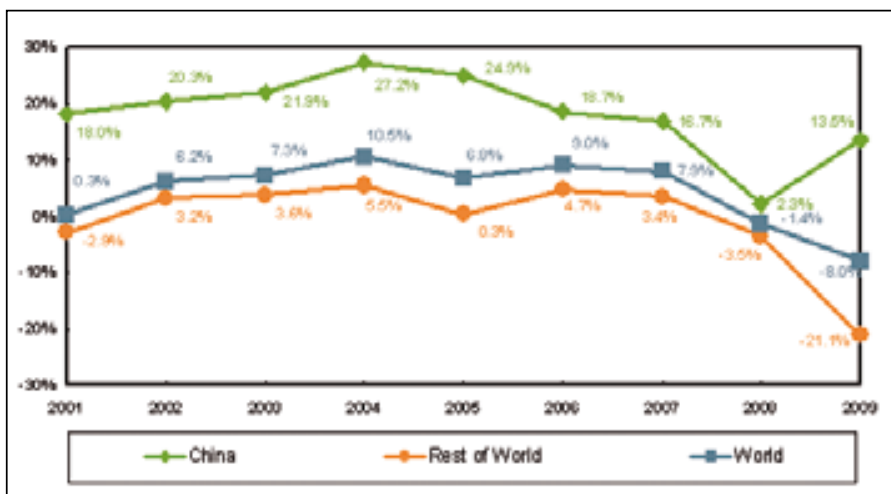

Crude steel production annual growth trend. Source: World Steel Association

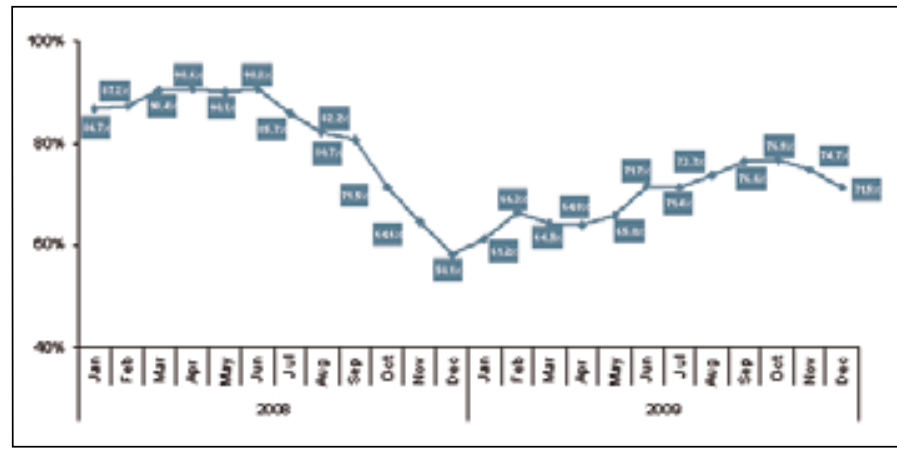

Global steel capacity utilisation ratio Source: World Steel Association

Top 10 steel-producing countries

\begin{tabular}{c|c|c|c|c}
\hline Rank & Country & 2009 & 2008 & $\%$ 2009/2008 \\
\hline 1 & China & 567.8 & 500.3 & 13.5 \\
\hline 2 & Japan & 87.5 & 118.7 & -26.3 \\
\hline 3 & Russia & 59.9 & 68.5 & -12.5 \\
\hline 4 & US & 58.1 & 91.4 & -36.4 \\
\hline 5 & India & 56.6 & 55.1 & 2.7 \\
\hline 6 & South Korea & 48.6 & 53.6 & -9.4 \\
\hline 7 & Germany & 32.7 & 45.8 & -28.7 \\
\hline 8 & Ukraine & 29.8 & 37.3 & -20.2 \\
\hline 9 & Brazil & 26.5 & 33.7 & -21.4 \\
\hline 10 & Turkey & 25.3 & 26.8 & -5.6 \\
\hline
\end{tabular}

Source: World Steel Association 


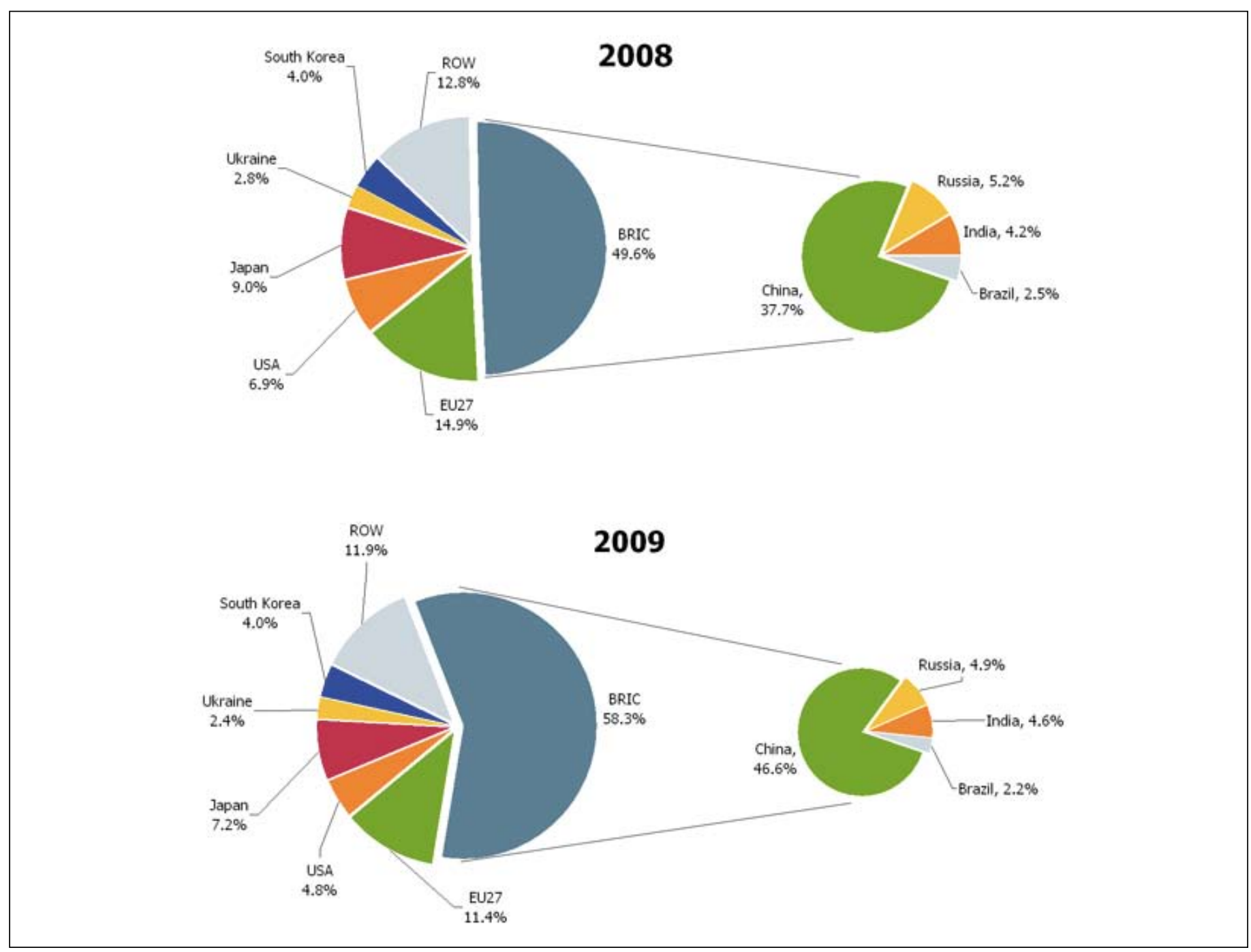

Figure 3: Share of world crude steel production 2008, 2009

\section{World crude steel production - Summary Table}

\begin{tabular}{|c|c|c|c|c|c|c|c|c|}
\hline Million metric tons & 2003 & 2004 & 2005 & 2006 & 2007 & 2008 & 2009 & $\% 2009 / 2008$ \\
\hline $\begin{array}{l}\text { Europe } \\
\text { of which: }\end{array}$ & 320.3 & 339.8 & 333.8 & 355.1 & 364.5 & 344.1 & 265.8 & -22.8 \\
\hline EU (27) & 192.5 & 202.5 & 195.6 & 207.0 & 209.7 & 198.0 & 139.1 & -29.7 \\
\hline EU (15) & 161.0 & 169.1 & 165.1 & 173.2 & 175.2 & 167.7 & 117.7 & -29.8 \\
\hline CIS & 106.5 & 113.4 & 113.2 & 119.9 & 124.2 & 114.3 & 97.5 & -14.7 \\
\hline $\begin{array}{l}\text { North America } \\
\text { of which: }\end{array}$ & 126.2 & 134.0 & 127.6 & 131.8 & 132.6 & 124.5 & 82.3 & -33.9 \\
\hline United States & 93.7 & 99.7 & 94.9 & 98.6 & 98.1 & 91.4 & 58.1 & -36.4 \\
\hline South America & 43.0 & 45.9 & 45.3 & 45.3 & 48.2 & 47.4 & 37.8 & -20.1 \\
\hline Africa & 16.3 & 16.7 & 18.0 & 18.8 & 18.8 & 17.1 & 15.2 & -11.0 \\
\hline Middle East & 13.4 & 14.3 & 15.3 & 15.4 & 16.5 & 16.6 & 17.2 & 3.3 \\
\hline $\begin{array}{l}\text { Asia } \\
\text { of which: }\end{array}$ & 442.3 & 512.5 & 595.5 & 672.3 & 756.5 & 768.3 & 795.4 & 3.5 \\
\hline China & 222.3 & 282.9 & 353.2 & 419.1 & 489.3 & 500.3 & 567.8 & 13.5 \\
\hline Japan & 110.5 & 112.7 & 112.5 & 116.2 & 120.2 & 118.7 & 87.5 & -26.3 \\
\hline Australia/New Zealand & 8.4 & 8.3 & 8.6 & 8.7 & 8.8 & 8.4 & 6.0 & -28.6 \\
\hline World & 969.9 & 1071.5 & 1144.1 & 1247.3 & 1345.8 & 1326.5 & 1219.7 & -8.0 \\
\hline
\end{tabular}




\section{The largest steel producing countries - million metric tons}

\begin{tabular}{|c|c|c|c|c|c|c|c|c|}
\hline Rank & Country & 2009 & 2008 & 2007 & 2006 & 2005 & 2004 & $\% 2009 / 2008$ \\
\hline 1 & China & 567.8 & 500.3 & 489.3 & 419.1 & 353.2 & 282.9 & 13.5 \\
\hline 2 & Japan & 87.5 & 118.7 & 120.2 & 116.2 & 112.5 & 112.7 & -26.3 \\
\hline 3 & Russia & 59.9 & 68.5 & 72.4 & 70.8 & 66.1 & 65.6 & -12.5 \\
\hline 4 & United States & 58.1 & 91.4 & 98.1 & 98.6 & 94.9 & 99.7 & -36.4 \\
\hline 5 & India & 56.6 & 55.1 & 53.1 & 49.5 & 45.8 & 32.6 & 2.7 \\
\hline 6 & South Korea & 48.6 & 53.6 & 51.5 & 48.5 & 47.8 & 47.5 & -9.4 \\
\hline 7 & Germany & 32.7 & 45.8 & 48.6 & 47.2 & 44.5 & 46.4 & -28.7 \\
\hline 8 & Ukraine & 29.8 & 37.3 & 42.8 & 40.9 & 38.6 & 38.7 & -20.2 \\
\hline 9 & Brazil & 26.5 & 33.7 & 33.8 & 30.9 & 31.6 & 32.9 & -21.4 \\
\hline 10 & Turkey & 25.3 & 26.8 & 25.8 & 23.3 & 21.0 & 20.5 & -5.6 \\
\hline 11 & Italy & 19.7 & 30.6 & 31.6 & 31.6 & 29.3 & 28.6 & -35.5 \\
\hline 12 & Taiwan, China & 15.7 & 19.9 & 20.9 & 20.0 & 18.9 & 19.6 & -20.8 \\
\hline 13 & Spain & 14.3 & 18.6 & 19.0 & 18.4 & 17.8 & 17.6 & -23.3 \\
\hline 14 & Mexico & 14.2 & 17.2 & 17.6 & 16.4 & 16.2 & 16.7 & -17.7 \\
\hline 15 & France & 12.8 & 17.9 & 19.2 & 19.9 & 19.5 & 20.8 & -28.2 \\
\hline 16 & Iran & 10.9 & 10.0 & 10.1 & 9.8 & 9.4 & 8.7 & 9.1 \\
\hline 17 & United Kingdom & 10.1 & 13.5 & 14.3 & 13.9 & 13.2 & 13.8 & -25.4 \\
\hline 18 & Canada & 9.0 & 14.8 & 15.6 & 15.5 & 15.3 & 16.3 & -39.6 \\
\hline 19 & South Africa & 7.5 & 8.3 & 9.1 & 9.7 & 9.5 & 9.5 & -9.5 \\
\hline 20 & Poland & 7.2 & 9.7 & 10.6 & 10.0 & 8.3 & 10.6 & -25.9 \\
\hline 21 & Malaysia (e) & 6.0 & 6.4 & 6.9 & 5.8 & 5.3 & 5.7 & -6.6 \\
\hline 22 & Austria & 5.7 & 7.6 & 7.6 & 7.1 & 7.0 & 6.5 & -25.4 \\
\hline 23 & Belgium & 5.6 & 10.7 & 10.7 & 11.6 & 10.4 & 11.7 & -47.2 \\
\hline 24 & Egypt & 5.5 & 6.2 & 6.2 & 6.0 & 5.6 & 4.8 & -11.1 \\
\hline 25 & Australia & 5.2 & 7.6 & 7.9 & 7.9 & 7.8 & 7.4 & -31.2 \\
\hline 26 & Netherlands & 5.2 & 6.9 & 7.4 & 6.4 & 6.9 & 6.8 & -24.2 \\
\hline 27 & Thailand (e) & 5.0 & 5.2 & 5.6 & 4.9 & 5.2 & 4.5 & -4.1 \\
\hline 28 & Saudi Arabia & 4.7 & 4.7 & 4.6 & 4.0 & 4.2 & 3.9 & 0.5 \\
\hline 29 & Czech Republic & 4.6 & 6.4 & 7.1 & 6.9 & 6.2 & 7.0 & -28.1 \\
\hline 30 & Kazakhstan & 4.1 & 4.3 & 4.8 & 4.3 & 4.5 & 5.4 & -2.4 \\
\hline 31 & Argentina & 4.0 & 5.5 & 5.4 & 5.5 & 5.4 & 5.1 & -27.6 \\
\hline 32 & Venezuela & 3.8 & 4.2 & 5.0 & 4.9 & 4.9 & 4.6 & -9.5 \\
\hline 33 & Slovakia & 3.7 & 4.5 & 5.1 & 5.1 & 4.5 & 4.5 & -16.5 \\
\hline 34 & Indonesia (e) & 3.5 & 3.9 & 4.2 & 3.8 & 3.7 & 3.7 & -10.6 \\
\hline 35 & Finland & 3.1 & 4.4 & 4.4 & 5.1 & 4.7 & 4.8 & -30.3 \\
\hline 36 & Sweden & 2.8 & 5.2 & 5.7 & 5.5 & 5.7 & 6.0 & -46.0 \\
\hline 37 & Romania & 2.7 & 5.0 & 6.3 & 6.3 & 6.3 & 6.0 & -46.4 \\
\hline 38 & Byelorussia & 2.4 & 2.6 & 2.4 & 2.3 & 2.0 & 1.8 & -6.6 \\
\hline 39 & Luxembourg & 2.2 & 2.6 & 2.9 & 2.8 & 2.2 & 2.7 & -14.2 \\
\hline \multirow[t]{3}{*}{40} & Greece & 2.1 & 2.5 & 2.6 & 2.4 & 2.3 & 2.0 & -15.9 \\
\hline & Others & 23.3 & 28.3 & 29.8 & 28.6 & 25.8 & 24.8 & -17.5 \\
\hline & World & 1219.7 & 1326.5 & 1345.8 & 1247.3 & 1144.1 & 1071.5 & -8.0 \\
\hline
\end{tabular}




\section{ArcelorMittal: \$0.1 billion net income in 2009}

ArcelorMittal's net income for the twelve months ended December 31,2009 was $\$ 0.1$ billion, as compared to net income for the twelve months ended December 31, 2008 of $\$ 9.4$ billion.

Sales and operating loss for the twelve months ended December 31,2009 were $\$ 65.1$ billion and $\$ 1.7$ billion, respectively, as compared with sales and operating income for the twelve months ended December 31,2008 , of $\$ 124.9$ billion and $\$ 12.2$ billion, respectively. Sales were lower due to lower average steel selling prices $(-27 \%)$ and lower steel shipment volumes $(-30 \%)$ due to a sharp drop in global steel demand following the global economic crisis.

Total steel shipments for the twelve months ended December 31, 2009 decreased to 71.1 million metric tonnes as compared with total steel shipments of 101.7 million metric tonnes for the twelve months ended December 31, 2008.

Shipments are expected to be higher during the first quarter of 2010 as compared to the fourth quarter of 2009, but this increase is expected to be offset by slightly lower average selling prices and increased costs. The company also expects net debt to increase in the first quarter of 2010.

The following tables summarise the company's principal growth and optimisation projects involving significant capital expenditure completed in 2009 and those that are currently ongoing.

Among recent developments, ArcelorMittal announced it had entered into initial discussions with BHP Billiton to potentially combine their respective iron ore mining and infrastructure interests in Liberia and Guinea within a joint venture. The iron ore interests of the two companies in Liberia and in Guinea are proximate and the parties believe they could be significantly more competitive if brought together in a combined operation.

\begin{tabular}{|lllll|}
\hline Segment & Site & Project & Capacity / particulars & Actual Completion \\
\hline FCA & $\begin{array}{l}\text { ArcelorMittal Tubarao } \\
\text { (Brazil) }\end{array}$ & $\begin{array}{l}\text { Hot strip mill expansion } \\
\text { project }\end{array}$ & $\begin{array}{l}\text { Hot strip mill capacity increase } \\
\text { from 2.7mt to 4 mt/year }\end{array}$ & $4 \mathrm{Q} 09$ \\
\hline FCA & $\begin{array}{l}\text { Volcan } \\
\text { (Mexico) }\end{array}$ & Mine development & $\begin{array}{l}\text { Production increase } \\
\text { of 1.6mt of iron ore in 2010 }\end{array}$ & $4 \mathrm{Q} 09$ \\
\hline
\end{tabular}

\begin{tabular}{|lllll|}
\hline Segment & Site & Project & Capacity / particulars & Actual Completion \\
\hline FCA & $\begin{array}{l}\text { ArcelorMittal Tubarao } \\
\text { (Brazil) }\end{array}$ & $\begin{array}{l}\text { Vega do Sul } \\
\text { expansion plan }\end{array}$ & $\begin{array}{l}\text { Increase in HDG production } \\
\text { of 350kt / year }\end{array}$ & $1 \mathrm{H} \mathrm{10}$ \\
\hline FCA & $\begin{array}{l}\text { ArcelorMittal Dofasco } \\
\text { (Canada) }\end{array}$ & $\begin{array}{l}\text { Primary steelmaking } \\
\text { optimisation }\end{array}$ & $\begin{array}{l}\text { Increase of slab } \\
\text { capacity by 630kt / year }\end{array}$ & $1 \mathrm{H} \mathrm{10}$ \\
\hline FCE & $\begin{array}{l}\text { ArcelorMittal Dunkerque } \\
\text { (France) }\end{array}$ & $\begin{array}{l}\text { Modernisation } \\
\text { of continuous caster 21 }\end{array}$ & $\begin{array}{l}\text { Slab capacity increase } \\
\text { from 6.7mt to 7.5mt / year }\end{array}$ & $2 \mathrm{H} \mathrm{10}$ \\
\hline FCA & $\begin{array}{l}\text { Princeton Coal } \\
\text { (USA) }\end{array}$ & Princeton Coal & $\begin{array}{l}\text { Capacity increase } \\
\text { of 0.7mt }\end{array}$ & 2010 \\
\hline AACIS & Liberia mines & Greenfield Liberia & $\begin{array}{l}\text { Iron ore production } \\
\text { of 15mt / year }\end{array}$ & $2011(2)$ \\
\hline LCA & $\begin{array}{l}\text { Monlevade } \\
\text { (Brazil) }\end{array}$ & $\begin{array}{l}\text { Monlevade } \\
\text { expansion plan }\end{array}$ & $\begin{array}{l}\text { Increase in capacity of finished } \\
\text { products by 1.150kt }\end{array}$ & 2012 \\
\hline FCA & $\begin{array}{l}\text { ArcelorMittal Mines } \\
\text { (Canada) }\end{array}$ & $\begin{array}{l}\text { Replacement of spirals } \\
\text { for enrichment }\end{array}$ & $\begin{array}{l}\text { Increase iron ore production } \\
\text { by 0.8mt / year }\end{array}$ & 2013 \\
\hline
\end{tabular}

1. Ongoing projects refer to projects in which construction has begun and exclude various projects that are under development such as in India.

2. Iron ore mining production is expected to commence in 2011 with initial production of 1 million tonnes.

Projects through joint ventures

\begin{tabular}{|lllll|}
\hline Country & Site & Project & Capacity & Forecast Completion \\
\hline Saudi Arabia & Al-Jubail & 600kt seamless tube mill & $\begin{array}{l}\text { Capacity of 600kt } \\
\text { of seamless tube }\end{array}$ & 2012 \\
\hline China & Hunan Province & VAMA Auto Steel JV & $\begin{array}{l}\text { Capacity of } 1.2 \mathrm{mt} \\
\text { for the auto market }\end{array}$ & 2012 \\
\hline China & Hunan Province & VAME Electrical Steel JV & Capacity of $0.3 \mathrm{mt}$ & 2012 \\
\hline
\end{tabular}


Besides, ArcelorMittal acquired a $28.8 \%$ stake in Uttam Galva Steels Limited ("Uttam Galva"), an Indian producer of cold rolled steel, galvanized products (including plain and corrugated) and color coated coils and sheets. The company expects to purchase an additional $4.9 \%$ from the Promoter R.K. Miglani family in due course.

\section{AK Steel: \$74.6 million loss in 2009}

For the full-year 2009, AK Steel reported a net loss of $\$ 74.6$ million, compared to net income of $\$ 4.0$ million, for 2008.

AK Steel produces flat-rolled carbon, stainless and electrical steels, primarily for automotive, appliance, construction and electrical power generation and distribution markets. The company employs about 6,200 men and women in Middletown, Mansfield, Coshocton and Zanesville, Ohio; Butler, Pennsylvania; Ashland, Kentucky; Rockport, Indiana; and its corporate headquarters in West Chester, Ohio.

Net sales for 2009 were $\$ 4,076.8$ million on shipments of $3,935,500$ tons, compared to sales of $\$ 7,644.3$ million and shipments of $5,866,000$ tons for 2008. AK Steel's average selling price for 2009 was $\$ 1,036$ per ton, approximately $20 \%$ below its 2008 average of $\$ 1,303$ per ton. According to AK Steel, the decline in shipments and revenues reflect the significant decline in the economy and the resultant decline in demand for steel products, especially in the first half of 2009. The company posted an operating loss for 2009 of $\$ 70.1$ million, or $\$ 18$ per ton, compared to operating profit of $\$ 28$ million, or $\$ 5$ per ton for 2008 .

\section{Nucor reports 2009 losses: $\$ 293.6$ million}

Nucor Corporation reported a consolidated net loss of $\$ 293.6$ million in 2009, compared with net earnings of $\$ 1.83$ billion for 2008 .

Nucor and affiliates are manufacturers of steel products, with operating facilities primarily in the U.S. and Canada.

For the full year 2009, Nucor's consolidated net sales decreased $53 \%$ to $\$ 11.19$ billion, compared with $\$ 23.66$ billion for 2008 . Average sales price per ton decreased $32 \%$ while total tons shipped to outside customers decreased $30 \%$ from 2008 levels.

Steel mill utilization rates decreased from $80 \%$ for the full year 2008 to $54 \%$ for the full year 2009 . The quarter over quarter decrease in utilization was due to fourth quarter seasonal issues that are separate of the general economic slowdown due to the holidays and year-end plant shutdowns by some of our customers.

\section{US Steel reports a $\$ 1,401$ million loss}

For full-year 2009, U.S. Steel reported a net loss of $\$ 1,401$ million, compared with full-year 2008 net income of $\$ 2,112$ million.

U. S. Steel Chairman and CEO John P. Surma said, "We reported a modest improvement in fourth quarter results as compared to the third quarter mainly due to higher average realized prices, increased shipments and higher utilization rates for our flat-rolled operations, prima- rily driven by North American automotive and service center markets, and the return to profitability of our tubular operations."

Management believes segment income from operations is a key measure to evaluate ongoing operating results and performance. U.S. Steel's reportable segments and Other Businesses reported a segment loss from operations of $\$ 245$ million, or $\$ 53$ per ton, in the fourth quarter of 2009 , compared with a loss of $\$ 379$ million, or $\$ 91$ per ton, in the third quarter of 2009 and income of $\$ 418$ million, or $\$ 100$ per ton, in the fourth quarter of 2008. Fourth quarter results for the Flat-rolled segment improved from the third quarter, primarily due to the benefits of higher average realized prices, increased shipments, and reduced facility restart costs. These favorable effects were somewhat offset by increased facility repair and maintenance costs at a number of steelmaking locations.

Shipments improved by 18 percent to 3.2 million tons while average realized prices increased by five percent to $\$ 633$ per net ton. In response to increased customer order rates, at the end of the fourth quarter, U.S. Steel was operating all of its available North American blast furnaces, except the \#14 Blast Furnace at Gary Works and the one blast furnace at Lake Erie Works, and restarted Keetac iron ore operations.

Raw steel capability utilization rates for the quarter increased to 64 percent versus 58 percent in the third quarter. Fourth quarter results reflected continuing employee and other costs for idled facilities totaling approximately $\$ 80$ million, primarily at Lake Erie Works, compared to $\$ 165$ million in the third quarter of 2009.

Tubular returned to profitability with operating income of $\$ 39$ million in the fourth quarter of 2009 , a substantial improvement from the third quarter. The improvement from third quarter results was mainly due to the benefits of higher shipments, operating efficiencies, and the favorable effect of adjustments related to employee layoff benefits and last-in, first-out (LIFO) inventory liquidations which totaled approximately $\$ 10$ million. Shipments were largely driven by increased demand for alloy and heat treated seamless tubular products, due in part to the continuing development of shale natural gas resources. Meanwhile, according to U. S. Steel, tubular markets continue to be negatively affected by continued high levels of carbon grade oil country tubular goods inventories created by high amounts of unfairly traded and subsidized imports from China in prior quarters. Average realized prices decreased by less than one percent to $\$ 1,462$ per net ton.

Fourth quarter results for U. S. Steel Europe (USSE) were slightly lower than the third quarter. As compared to the third quarter, the benefits of higher average realized prices were offset by higher costs for raw materials. Raw steel capability utilization rates decreased to 80 percent in the fourth quarter versus 82 percent in the third quarter, as the impact from a planned maintenance outage for one of three blast furnaces at U. S. Steel Kosice (USSK) was partially offset by increased production at U. S. Steel Serbia. Shipments decreased by three percent to 1.2 million tons while reported average realized prices increased by eight percent to $\$ 664$ per net ton.

Commenting on U. S. Steel's outlook, Surma said, "We expect to report an overall first quarter 2010 operating loss in line with the fourth quarter 2009 as gradually improving business conditions are not yet fully reflected in our operating results. We continue to experience improved order rates from several of our end markets. Automotive, service 
center, converter and appliance customer order rates in North America and Europe are at or near their highest levels in the last twelve months, while in other markets, such as construction in North America, demand remains soft."

\section{EMF signs agreement with ArcelorMittal}

The European Metalworkers' Federation (EMF) and ArcelorMittal European management signed an agreement, on 2nd November 2009, which means to provide guarantees for the 115,000 workers employed by ArcelorMittal in Europe.

The EMF, as representative body defending the interests of workers in the European metal industry, has a mandate for the external representation and coordination of the metalworkers' unions and a mandate to engage in bargaining at European level. For Bart Samyn, EMF Deputy General Secretary, "This agreement is a step in the right direction in the current period of uncertainty. It gives guarantees for workers' employability and the long-term industrial development of ArcelorMittal in Europe. The EMF trusts that the agreement will be swiftly implemented in all the European ArcelorMittal sites. The EMF will be vigilant about ensuring the full application of the agreement."

Whereas workers have been highly concerned about the risk of permanent closure of some of the industrial sites and blast furnaces, the agreement confirms that all the plants will be restarted and that no compulsory redundancies will take place. Furthermore, this agreement aims at implementing transformations in the steel industry in Europe that will ensure competitiveness and long-term sustainability. Among other initiatives, it promotes a long-term skill development and training policy within the group, improved social dialogue at national level and the setting up of such dialogue where it does not yet exist.

Michel Wurth, member of the General Management Board responsible for ArcelorMittal Flat Products Europe, commented: "Making Europe's steel industry competitive and secure now and for the next 20 years is a challenge that deserves to be dealt with in partnership. The Social Dialogue Group created by this agreement is a good forum to work together on such fundamental challenges".

\section{Carrington Wire closes Elland plant}

Based in Elland, West Yorkshire, Carrington Wire announced that it will be implementing a managed wind down of the business given continuing losses resulting from the contraction of the market for steel wire. This will include the closure of the Elland manufacturing plant over the coming months. Carrington Wire, acquired by Severstal-Metiz in April 2006, has experienced declining sales over the last years.

"We have worked hard over recent years to establish a sustainable business. In spite of financial support and initiatives to return the business to profitability, including the consolidation of manufacturing at Elland, Carrington Wire is no longer viable", said Oleg Veter, CEO of Severstalmetiz group of companies.

\section{ORE AND MINING}

\section{$=J F E$ Steel to acquire $20 \%$ interest in Byerwen coal project from QCoal Pty in Australia}

JFE Steel Corporation will acquire a 20\% interest in the Byerwen Coal project from QCoal Pty, which is expected to start production in 2012 in the northern Bowen Basin of northeastern Queensland, Australia. The two companies also have agreed to a long-term off-take contract for JFE steel to take annual delivery of 2.0 million tons of premium hard coking coal to be delivered from the Byerwen Coal project.

QCoal began operating Sonoma coal mine in 2007, which now produces four million tons annually. JFE Steel has participated in the mine since the development stage, including the acquisition of an interest in the mine through JFE Shoji Trade Corporation.

The proposed open-cut mine will produce 10 million tons of premium hard coking coal per annum as one of the largest coal mines in Australia. The port of Abbot Point serving the Byerwen Coal project has capacity to ensure shipments. Also, the geological conditions of the project are considered ideal for open-cut mining.

\section{The European Commission opens cartel investigation against mining companies joint venture}

Eurofer, the European Confederation of Iron and Steel Industries, warned about the BHP Billiton / Rio Tinto joint venture project: "The joint venture which has been agreed by BHP Billiton and Rio Tinto will combine their production and infrastructure facilities and will unavoidably lead to market concentration and an increase in pricing power of the combined company which is unacceptable in competition terms", said Eurofer director general Gordon Moffat. "We believe that this is a full-function joint venture which will not be different from the full merger attempted in 2008. It must be fully examined by the European competition authorities."

Following Eurofer's request, The European Commission opened an investigation according to article 101 of the Treaty on the Functioning of the European Union (TFEU), on the impact on the common market by the proposed joint venture between BHP Billiton and Rio Tinto.

"The resulting restriction in competition moving from a position of market dominance of three companies to only two will substantially reduce the consumer choice of supplier. It effectively creates a duopoly with the iron ore market for the entire world in the hands of just two companies ", according to Eurofer. BHP Billiton and Rio Tinto have market shares of seaborne iron ore of $17 \%$ and $19 \%$ respectively, while Vale, the third mining giant, controls $33 \%$ (2008). 